\title{
- Seasonal variation in the effectiveness of anticoagulation therapy of adults with atrial fibrillation: is the international normalized ratio value higher in summer time?
}

\author{
Karlo Golubić', \\ Petra Angebrandt ${ }^{2 *}$, \\ Irena Ivanac Vranešić², \\ Viktorija Ana Buljević², \\ Josip Kuharić², \\ Ivana Jonjić ${ }^{3}$, \\ Ivana Ježić ${ }^{3}$, \\ Nikola Bulj', \\ Diana Delić-Brkljačić', \\ Anton Šmalcelj², \\ Martina Lovrić Benčić ${ }^{3}$
}

'University Hospital Centre "Sestre milosrdnice", Zagreb, Croatia

${ }^{2}$ University of Zagreb School of Medicine, University Hospital Centre Zagreb, Zagreb, Croatia

${ }^{3}$ Health Center Zagreb Center, Zagreb, Croatia

${ }^{4}$ Health Center BjelovarskoBilogorska County, Croatia
RECEIVED:

September 24, 2017

ACCEPTED:

September 26, 2017

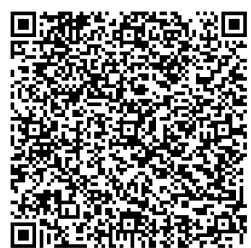

KEYWORDS: atrial fibrillation, variations, season, INR value.

CITATION: Cardiol Croat. 2017;12(9-10):373. | https://doi.org/10.15836/ccar2017.373

*ADDRESS FOR CORRESPONDENCE: Petra Angebrandt, Klinički bolnički centar Zagreb, Kišpatićeva 12, HR-10000 Zagreb, Croatia. / Phone: +385-91-1596-814 / E-mail: petraang37@yahoo.com

ORCID: Karlo Golubić, http://orcid.org/0000-0003-0684-6333 • Petra Angebrandt, http://orcid.org/0000-0001-5431-9736 Irena Ivanac Vranešić, http://orcid.org/0000-0002-6910-9720 • Viktorija Ana Buljević, http://orcid.org/0000-0002-0320-2623 Ivana Ježić, http://orcid.org/0000-0003-0075-9001 • Nikola Bulj, http://orcid.org/0000-0002-7859-3374

Diana Delić-Brkljačić, http://orcid.org/0000-0002-7116-2360 • Anton Šmalcelj, http://orcid.org/0000-0002-4497-542X Martina Lovrić Benčić, http://orcid.org/0000-0001-8446-6120

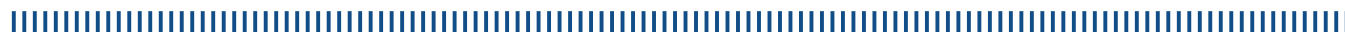
Introduction: The effectiveness and safety of treatment with warfarin are critically dependent on maintaining the international normalized ratio (INR) in the therapeutic range. Besides the dose of warfarin, many factors which interact with the metabolism of warfarin may influence the stability of treatment and the time in which patients' INRs are in the therapeutic range. ${ }^{1,2}$ Aim: To establish whether there is a significant seasonal variation in effectiveness of warfarin therapy in adults with atrial fibrillation in a Croatian population.

Patients and Methods: We conducted an observational study of a subgroup of patients enrolled in the AMACADo - Atrial fibrillation associated thromboembolic risk MAnagement in CroatiA national Database project, involving 2326 electronic medical records of patients with AF hospitalized in UHC Zagreb from 2010 until 2015. Out of 2326 patients we selected 1110 that were treated with warfarin as permanent anticoagulant therapy, prior to hospitalization, and the rest of patients we excluded from the research. Patient were divided in two categories based on INR values higher than $2.0($ INR > 2.0) and less or equal than 2.0 (INR $\leq 2.0$ ). Furthermore, we analyzed seasonal variation in the INR value during four seasons: spring, summer, autumn and winter. The $\mathrm{x}^{2}$ test was used for comparison of categorical variables

Results: Out of 239 patients admitted to hospital during summer 111 had an INR value $>2.0,(46.4 \%)$ in comparison with patients admitted during all other seasons (spring, autumn and winter) (324/871, $37.2 \%)$. Our results show that a larger proportion of patients was effectively anticoagulated during summer vs. other seasons ( $\mathrm{p}=0.00950174$, CI 95\%).

Conclusion: A seasonal variation in the INR values was observed among adults with atrial fibrillation, possibly due to many different factors such as variations in diet, hydration status and physical activity, and possibly therapy guidance. Seasonal variations in the intensity of warfarin therapy should always be considered in trials exploring thromboembolic complications of atrial fibrillation. The causes of this variations should be further investigated.

LITERATURE IIIIIIIIIIIIIIIIIIIIIIIIIIIIIIIIIIIIIIIIIIIIIIIIIIIIIIIIIIIIIIIIIIIIIIIIIIIIIIIIIIIIIIIIIIIIIIIIIIIIIIIIIII 1. lijima S, Sekii K, Baba T, Ueno D, Ohishi A. Seasonal variation in the international normalized ratio of neonates and its relationship with ambient temperature. BMC Pediatr. 2016 Jul 19;16:97. https://doi.org/10.1186/s12887-016-0639-1

2. Salobir B, Sabovic M, Peternel P. Intensity of long-term treatment with warfarin is influenced by seasonal variations. Pathophysiol Haemost Thromb. 2002 Jul-Aug;32(4):151-4. https://doi.org/10.1159/000070419 